\title{
Gambaran Bakteri Penyebab Infeksi Pada Anak Berdasarkan Jenis Spesimen dan Pola Resistensinya di Laboratorium RSUP Dr. M. Djamil Padang Tahun 2014-2016
}

\author{
M. Fadila Arie Novard ${ }^{1}$, Netti Suharti², Roslaili Rasyid ${ }^{2}$
}

\begin{abstract}
Abstrak
Penyakit infeksi merupakan masalah kesehatan masyarakat utama bagi negara maju dan berkembang. Salah satu penyebab infeksi adalah bakteri dan bisa menyerang berbagai sistem organ tubuh anak. Untuk mengobatinya digunakan antibiotik. Namun, dalam penggunaannya ditemukan resistensi antibiotik terhadap bakteri. Tujuan penelitian adalah mengetahui bakteri penyebab infeksi pada anak dan pola resistensinya dari berbagai spesimen tahun 2014-2016. Jenis penelitian adalah penelitian deskriptif restrospektif. Sampel penelitian adalah catatan hasil pemeriksaan kultur dari berbagai spesimen dan uji sensitivitas bakteri terhadap antibiotik pasien usia kurang dari 18 tahun di Laboratorium Mikrobiologi RSUP Dr. M. Djamil Padang periode 1 Januari 2014 - 31 Desember 2016. Dari hasil penelitian didapatkan bakteri penyebab infeksi pada anak dari spesimen darah adalah Klebsiella sp. Klebsiella sp. sensitif terhadap sulbaktamsefoperazon (95\%) dan netilmisin (86\%), dan rata-rata sudah resisten terhadap asam nalidiksat $(100 \%)$ dan eritromisin $(95,7 \%)$. Pada spesimen feses dan urin ditemukan Escherichia coli. Pada spesimen feses, Escherichia coli sensitif terhadap sulbaktam-sefoperazon $(97,7 \%)$ dan meropenem (95,7\%), resisten terhadap eritromisin (98\%) dan ampisilin (95,3\%). Pada spesimen urin, Escherichia coli sensitif terhadap meropenem (86,9\%) dan netilmisin $(76,9 \%)$, resisten terhadap tetrasiklin $(91,2 \%)$ dan amoksisilin (89,9\%). Pada spesimen sputum ditemukan Klebsiella $s p$. Klebsiella $s p$. sensitif terhadap meropenem $(84,2 \%)$ dan levofloksasin $(76,9 \%)$, resisten terhadap sulfametroksazol-trimetroprim $(100 \%)$ dan eritromisin $(93,8 \%)$. Kesimpulan penelitian adalah bakteri yang paling banyak menjadi penyebab infeksi pada spesimen darah anak adalah Klebsiella sp. yang sensitif terhadap sulbaktam-sefoperazon dan resisten terhadap asam nalidiksat. Pada spesimen feses, Escherichia coli sensitif terhadap sulbaktam-sefoperazon dan resisten terhadap eritromisin. Pada spesimen urin, Escherichia coli sensitif terhadap meropenem dan resisten terhadap tetrasiklin. Pada spesimen sputum, Klebsiella sp. sensitif terhadap meropenem dan resisten terhadap sulfametroksazol-trimetroprim.
\end{abstract}

Kata kunci: bakteri, antibiotik, pola resistensi

\section{Abstract}

Infectious diseases are a major public health problem for developed and developing countries. One of the causes of infection is bacteria and can attack various organ systems of the child's body. To treat it is used antibiotics. However, in its use found antibiotic resistance to bacteria. The purpose of this research is to know the infant causing bacteria and its resistance pattern from various specimen in 2014-2016. This type of research is a retrospective descriptive study. The sample of the study was a record of culture examination results from various specimens and bacterial sensitivity test on antibiotics of patients aged less than 18 years in Microbiology Laboratory of Dr. M. Djamil Padang period January 1 , 2014 - December 31, 2016. From the results obtained bacteria cause infections in children from blood specimens is Klebsiella sp. Klebsiella sp. sensitive to sulbactam-cefoperazon (95\%) and netilmicin (86\%), and on average already resistant to nalidixic acid (100\%) and erythromycin (95.7\%). In fecal and urine specimens Escherichia coli was found. In faecal specimens, Escherichia coli is sensitive to sulbactam-cefoperazon (97.7\%) and meropenem (95.7\%), resistant to erythromycin (98\%) and ampicillin (95.3\%). In urine specimens Escherichia coli is sensitive to meropenem (86.9\%) and netilmicin (76.9\%), resistant to tetracycline (91.2\%) and amoxicillin (89.9\%). In sputum specimens found Klebsiella sp. Klebsiella sp. sensitive to meropenem (84.2\%) and levofloxacin (76.9\%), resistant to sulfamethroxazole-trimethroprim (100\%) and erythromycin (93.8\%). The conclusion of the study was that the bacteria that caused the most infection in blood specimens of children was Klebsiella sp. which are sensitive to sulbactam-cefoperazon and resistant to nalidixic acid. In fecal specimens, Escherichia coli is sensitive to sulbactam-cephoperazon and resistant to erythromycin. In urine specimens, Escherichia coli is sensitive to meropenem and resistant to tetracycline. In sputum specimens, Klebsiella sp. sensitive to meropenem and resistant to sulfamethroxazole-trimethroprim.

Keywords: bacteria, antibiotics, resistance patterns

Affiliasi penulis : 1. Profesi Dokter FK UNAND (Fakultas Kedokteran Universitas Andalas Padang), 2. Bagian Mikrobiologi FK UNAND/RSUP Dr. M. Djamil Padang

Korespondensi :M. Fadila Arie Novard, email: arienovard46@gmail.com Telp: 081266659988

\section{PENDAHULUAN}

Penyakit infeksi merupakan salah satu masalah kesehatan masyarakat yang utama di negara maju dan berkembang. World Health Organization (WHO) 
mengemukakan bahwa penyakit ini merupakan penyebab utama kematian pada anak-anak. Data WHO tahun 2012 menyatakan bahwa tingkat kematian anak $<5$ tahun di Indonesia disebabkan oleh penyakit infeksi dengan persentase 1-20\%. ${ }^{1}$

Penyakit infeksi ialah penyakit yang disebabkan oleh masuk dan berkembangnya biaknya mikroorganisme, suatu kelompok luas dari organisme mikroskopik yang terdiri dari satu atau banyak sel seperti bakteri, fungi, dan parasit serta virus. ${ }^{2}$ Penyakit infeksi terjadi ketika interaksi dengan mikroba menyebabkan kerusakan pada tubuh host dan kerusakan tersebut menimbulkan berbagai gejala dan tanda klinis. Mikroorganisme yang menyebabkan penyakit pada manusia disebut sebagai mikroorganisme patogen, salah satunya bakteri patogen. ${ }^{3}$

Infeksi bakteri dapat terjadi pada anak dan menyerang berbagai sistem organ pada tubuh anak. Infeksi saluran pernapasan (27\%) bakteri yang sering menjadi penyebab infeksi adalah Streptococcus pneumoniae, Streptococcus grup A, dan Haemophilus influenzae tipe B. ${ }^{4}$ Infeksi kulit (7-10\%) pada anak biasa disebabkan oleh Staphylococcus aureus atau Streptococcus grup $A .{ }^{5}$ Infeksi saluran pencernaan (5\%) sering disebabkan oleh Shigella, Escherichia coli, Campylobacter. ${ }^{6}$ Infeksi saluran urinarius $(0,7-0,9 \%)$ sering disebabkan oleh Escherichia coli, Klebsiella pneumoniae, Proteus mirabilis. ${ }^{7,8}$

Antibiotik merupakan obat yang digunakan pada infeksi yang disebabkan oleh bakteri. $^{9}$ Untuk menentukan antibiotik spesifik yang akan digunakan, dilakukan pemeriksaan secara mikrobiologis, seperti isolasi organisme patogen dari spesimen tubuh yang steril dan uji sensitifitas antimikroba. ${ }^{10}$ Penanganan infeksi kemudian dilakukan setelah didapatkan bakteri yang menginfeksi. Beberapa contoh antibiotik yang diberikan seperti amoksisilin untuk infeksi oleh bakteri Gram-positif, kloramfenikol pada infeksi oleh bakteri Gram-positif dan bakteri Gram-negatif, klindamisin pada infeksi oleh bakeri Gram-positif (kecuali Enterococcus), eritromisin untuk infeksi oleh bakteri Gram-positif, Corynebacterium diphtheriae, dan Mycoplasma pneumoniae, gentamisin pada infeksi bakteri basil Gram-negatif, ciprofloksasin pada infeksi oleh Streptococcus pyogenes, Shigella, Salmonella,
Enterobacter, Pseudomonas aeruginosa, penisilin pada infeksi oleh Streptococcus grup A, Treponema pallidum, dan Neisseria meningitidis, sulfadiazin pada infeksi saluran urinarius oleh Escherichia coli, Klebisella, dan Proteus mirabilis. ${ }^{10}$

Masalah yang sering terjadi adalah penanganan infeksi anak dilakukan berdasarkan diagnosis klinis dengan antibiotik empiris sebelum atau bahkan tanpa mengidentifikasi mikroorganisme patogen spesifik. ${ }^{10}$ Kondisi ini didukung dengan situasi di Indonesia, seperti keterbatasan sarana diagnostik, keterbatasan cakupan asuransi kesehatan serta kekhawatiran akan terjadi infeksi bakterial yang berat, sehingga dokter pada umumnya memilih untuk segera memberikan antibiotik segera setelah mendapatkan pasien dengan demam. ${ }^{11}$

Penelitian pendahuluan Antimicrobial Resistance in Indonesia, Prevalence and Prevention (AMRIN) Study pada tahun 2001 di bangsal rawat inap anak RS Dr. Kariadi Semarang dan RS Dr. Soetomo Surabaya, mendapatkan bahwa tingkat konsumsi antibiotik sangat tinggi (lebih dari 90\% pasien yang dirawat di rumah sakit tersebut mendapatkan antibiotik). ${ }^{11}$ Diperkirakan pemberian antibiotik 2-4 kali lebih banyak pada anak setiap tahunnya dan durasi penggunaannya rata-rata 4 kali lebih lama. ${ }^{12}$

Hasil penelitian dari studi Antimicrobial Resistence in Indonesia (AMRIN study) terbukti dari 2494 individu di masyarakat, 43\% Escherichia coli resisten terhadap berbagai jenis antibiotik antara lain ampisilin (34\%), kotrimoksazol (29\%), dan kloramfenikol (25\%). Hasil penelitian 781 pasien yang dirawat di rumah sakit didapatkan $81 \%$ Escherichia coli resisten terhadap beberapa jenis antibiotik yaitu ampisilin (73\%), kotrimoksazol (56\%), kloramfenikol $(43 \%)$, siprofloksasin $(22 \%)$, dan gentamisin (18\%). ${ }^{13,14}$

Lebih dari $50 \%$ bakteri Escherichia coli resisten terhadap antibiotik sefepim, seftazidim, seftriakson, siprofloksasin, gentamisin dan trimetoprim/sulfametoksazol. Bakteri Klebsiella pneumonia resisten terhadap antibiotik seftazidim, seftriakson dan trimetoprim/sulfametoksazol masingmasing sebesar $100 \%$. Bakteri Proteus mirabilis resistensi terhadap antibiotik seftazidim, seftriakson, siprofloksasin, gentamisin dan 
trimetoprim/sulfametoksazol masing-masing sebesar $100 \%$ di RSUD Dr. Moewardi tahun 2014..$^{15}$

Berdasarkan uraian di atas terlihat adanya berbagai bakteri yang dapat menginfeksi anak dan resistensi antibiotik, maka penulis tertarik untuk mengetahui bakteri penyebab infeksi pada anak dan pola resistensinya.

\section{METODE}

Jenis penelitian ini adalah deskriptif retrospektif. Variabel penelitian adalah bakteri dari berbagai spesimen dan sensitivitas terhadap antibiotik. Penelitian dilakukan dari bulan Februari-Maret 2018 di Laboratorium Mikrobiologi RSUP Dr. M. Djamil Padang.

Populasi penelitian ini adalah semua hasil pemeriksaan kultur dari berbagai spesimen dan uji sensitivitas bakteri terhadap antibiotik pada pasien dengan usia kurang dari 18 tahun di Laboratorium Mikrobiologi RSUP Dr. M. Djamil Padang.

Sampel penelitian yang dipilih adalah hasil pemeriksaan kultur dari berbagai spesimen dan uji sensitivitas bakteri terhadap antibiotik pada pasien dengan usia kurang dari 18 tahun di Laboratorium Mikrobiologi RSUP Dr. M. Djamil Padang dalam kurun waktu 1 Januari 2014 - 31 Desember 2016.

Data diperoleh dari data laboratoirum. Kemudian data dianalisis secara statistik berdasarkan variabel yang dinilai menggunakan sistem komputerisasi yaitu analisis univariat. Analisis univariat dilakukan untuk melihat distribusi frekuensi dari masing-masing variabel.

\section{HASIL}

Penelitian dilakukan dengan menggunakan data sekunder yang diperoleh dari buku hasil pemeriksaan uji kultur dan sensitivitas antibiotik terhadap bakteri di Laboratorium Mikrobiologi Klinik RSUP Dr. M. Djamil Padang periode Januari 2014 sampai dengan Desember 2016 dari berbagai spesimen yang telah di periksa.

Bakteri Penyebab Infeksi Pada Anak Dari Berbagai Spesimen

Tabel 1. Distribusi frekuensi bakteri penyebab infeksi pada anak di RSUP Dr. M. Djamil Padang tahun 20142016 pada berbagai spesimen

\begin{tabular}{lllllll} 
Bakteri & \multicolumn{2}{c}{2014} & \multicolumn{2}{c}{2015} & \multicolumn{2}{c}{2016} \\
\cline { 2 - 7 } & $\mathrm{n}$ & $\%$ & $\mathrm{n}$ & $\%$ & $\mathrm{n}$ & $\%$ \\
\hline
\end{tabular}

\begin{tabular}{lcccccc}
\hline Darah & & & & & & \\
Klebsiella sp. & 72 & 60.5 & 34 & 27.6 & 43 & 37.7 \\
S. aureus & 22 & 18.5 & 23 & 18.7 & 40 & 35.1 \\
Feses & & & & & & \\
Escherichia coli & 103 & 74.6 & 76 & 69.7 & 98 & 76.0 \\
Klebsiella sp. & 18 & 13.0 & 11 & 10.1 & 25 & 19.4 \\
Urin & & & & & & \\
Escherichia coli & 22 & 45.8 & 57 & 49.6 & 60 & 53.6 \\
Klebsiella sp. & 5 & 10.4 & 10 & 8.7 & 23 & 20.5 \\
Sputum & & & & & & \\
Klebsiella sp. & & & & & 20 & 33.9 \\
$P$. aeruginosa & & & & & 10 & 16.9 \\
\hline
\end{tabular}

Berdasarkan tabel 1 dapat dilihat bahwa bakteri yang menjadi penyebab infeksi pada anak dari spesimen darah dan sputum tahun 2014-2016 adalah Klebsiella sp. Pada spesimen feses dan urin adalah Escherichia coli.

Pola Resistensi Antibiotik Terhadap Bakteri Pada Spesimen Darah

Tabel 2. Pola resistensi antibiotik terhadap bakteri pada spesimen darah di RSUP Dr. M. Djamil Padang tahun 2014-2016

\begin{tabular}{|c|c|c|c|c|}
\hline \multirow{2}{*}{ MIKROBA } & \multicolumn{2}{|c|}{$\begin{array}{c}\text { Klebsiella } \\
\text { sp. } \\
(n=149)\end{array}$} & \multicolumn{2}{|c|}{$\begin{array}{c}\text { Staphylococcus } \\
\text { aureus } \\
(\mathrm{n}=85)\end{array}$} \\
\hline & $\begin{array}{c}\mathrm{S} \\
(\%)\end{array}$ & $\begin{array}{c}\mathrm{R} \\
(\%)\end{array}$ & $\begin{array}{l}\mathrm{S} \\
(\%)\end{array}$ & $\begin{array}{c}R \\
(\%)\end{array}$ \\
\hline Ampicillin & 7.6 & 92.4 & 11.5 & 88.5 \\
\hline $\begin{array}{l}\text { Ampicillin + } \\
\text { Sulbactam }\end{array}$ & 45.9 & 54.1 & 85.7 & 14.3 \\
\hline Amoxilin & 15.5 & 84.5 & 14.8 & 85.2 \\
\hline $\begin{array}{l}\text { Amoxilin + Cluvanic } \\
\text { Acid }\end{array}$ & 28.9 & 71.1 & 73.4 & 26.6 \\
\hline Nalidixid Acid & 0 & 100 & - & - \\
\hline Cholaramphenicol & 48.8 & 51.2 & 61.8 & 38.2 \\
\hline Erithromycin & 4.3 & 95.7 & 45 & 55 \\
\hline $\begin{array}{l}\text { Sulfametrhoxazole + } \\
\text { Trimetrhoprime }\end{array}$ & 50.7 & 49.3 & 45 & 55 \\
\hline Nitrfurantion & 32.4 & 67.6 & 63.8 & 36.2 \\
\hline Gentamycin & 47.9 & 52.1 & 78.1 & 21.9 \\
\hline Ciprofloxacin & 62.2 & 37.8 & 73.3 & 26.7 \\
\hline Ceftriaxone & 34.4 & 65.6 & 54 & 46 \\
\hline Ceftazidim & 52.2 & 47.8 & 48.7 & 51.3 \\
\hline Netilmicin & 86 & 14 & 94.7 & 5.3 \\
\hline Cefoperazone & 33.4 & 66.6 & 72.5 & 27.5 \\
\hline $\begin{array}{l}\text { Sulbactam + } \\
\text { Cefoperazone }\end{array}$ & 95 & 5 & 88.9 & 11.1 \\
\hline Meropenem & 80.3 & 19.7 & 77.9 & 22.1 \\
\hline Fosfomycin & 66.8 & 33.2 & 78.4 & 21.6 \\
\hline Levofloxacin & 77.5 & 22.5 & 78.4 & 21.6 \\
\hline Amikacin & - & - & 100 & - \\
\hline Novobiocin & - & - & 100 & - \\
\hline Cefoxitin & - & - & 100 & - \\
\hline Vancomicin & - & - & 100 & - \\
\hline
\end{tabular}

Berdasarkan tabel 2 Klebsiella $s p$. masih sensitif terhadap sulbaktam-sefoperazon (95\%) dan netilmisin 
(86\%), tetapi rata-rata sudah resisten terhadap asam nalidiksat $(100 \%)$ dan eritromisin $(95,7 \%)$. Sedangkan Staphylococcus aureus sensitif terhadap ampisilinsulbaktam (85,7\%) dan netilmisin (94,7\%) namun resisten terhadap ampisilin (88,5\%) dan amoksisilin $(85,2 \%)$.

Pola Resistensi Antibiotik Terhadap Bakteri Pada Spesimen Feses

Tabel 3 Pola resistensi antibiotik terhadap bakteri pada spesimen feses di RSUP Dr. M. Djamil Padang tahun 2014-2016

\begin{tabular}{|c|c|c|c|c|}
\hline \multirow[t]{2}{*}{ BAKTERI } & \multicolumn{2}{|c|}{$\begin{array}{c}\text { Escherichia } \\
\text { coli } \\
(\mathrm{n}=277)\end{array}$} & \multicolumn{2}{|c|}{$\begin{array}{c}\text { Klebsiella } \\
\text { sp. } \\
(\mathrm{n}=54)\end{array}$} \\
\hline & $\begin{array}{l}S \\
(\%)\end{array}$ & $\begin{array}{l}\mathrm{R} \\
(\%)\end{array}$ & $\begin{array}{c}\mathrm{S} \\
(\%)\end{array}$ & $\begin{array}{c}\mathrm{R} \\
(\%)\end{array}$ \\
\hline Ampicillin & 4.7 & 95.3 & 0 & 100 \\
\hline Ampicillin + Sulbactam & 47.8 & 52.2 & 0 & 100 \\
\hline Amoxilin & 6.4 & 93.6 & 0 & 100 \\
\hline $\begin{array}{l}\text { Amoxilin + Cluvanic } \\
\text { Acid }\end{array}$ & 33.8 & 66.2 & 35.1 & 64.9 \\
\hline Nalidixid Acid & 42.5 & 57.5 & 51.9 & 48.1 \\
\hline tetracylin & 14.9 & 85.1 & 11.1 & 88.9 \\
\hline Cholaramphenicol & 35.1 & 64.9 & 23.4 & 76.6 \\
\hline Erithromycin & 2 & 98 & 0 & 100 \\
\hline $\begin{array}{l}\text { Sulfametrhoxazole + } \\
\text { Trimetrhoprime }\end{array}$ & 16.3 & 83.7 & 28.5 & 71.5 \\
\hline Nitrfurantion & 54.2 & 45.8 & 41.3 & 58.7 \\
\hline Gentamycin & 59.3 & 40.7 & 53.6 & 46.4 \\
\hline Ciprofloxacin & 58.8 & 41.2 & 72.2 & 27.8 \\
\hline Ceftriaxone & 53.4 & 46.6 & 41.6 & 58.4 \\
\hline Ceftazidim & 72.9 & 27.1 & 63 & 37 \\
\hline Netilmicin & 92.4 & 7.6 & 86.7 & 13.3 \\
\hline Cefoperazone & 40.2 & 59.8 & 25.3 & 74.6 \\
\hline $\begin{array}{l}\text { Sulbactam + } \\
\text { Cefoperazone }\end{array}$ & 97.7 & 2.3 & 80 & 20 \\
\hline Meropenem & 95.7 & 4.3 & 86.5 & 13.5 \\
\hline Fosfomycin & 72.7 & 27.3 & 75.8 & 24.2 \\
\hline Levofloxacin & 72.6 & 27.4 & 84.7 & 15.3 \\
\hline
\end{tabular}

Berdasarkan tabel 3 Escherichia coli masih sensitif terhadap sulbaktam-sefoperazon (97,7\%) dan meropenem (95,7\%), tetapi resisten terhadap eritromisin (98\%) dan ampisilin (95,3\%). Klebsiella $s p$. sensitif terhadap netilmisin $(86,7 \%)$ dan meropenem $(86,5 \%)$, namun resisten terhadap ampisilin, amoksisilin, dan eritromisin (100\%).
Pola Resistensi Antibiotik Terhadap Bakteri Pada Spesimen Urin

Tabel 4 Pola resistensi antibiotik terhadap bakteri pada spesimen urin di RSUP Dr. M. Djamil Padang tahun 2014-2016

\begin{tabular}{|c|c|c|c|c|}
\hline \multirow[t]{2}{*}{ BAKTERI } & \multicolumn{2}{|c|}{$\begin{array}{c}\text { Escherichia } \\
\text { coli } \\
(n=139)\end{array}$} & \multicolumn{2}{|c|}{$\begin{array}{c}\text { Klebsiella } \\
\text { sp. } \\
(\mathrm{n}=38)\end{array}$} \\
\hline & $\begin{array}{l}\mathrm{S} \\
(\%)\end{array}$ & $\begin{array}{l}\mathrm{R} \\
(\%)\end{array}$ & $\begin{array}{l}\mathrm{S} \\
(\%)\end{array}$ & $\begin{array}{l}\mathrm{R} \\
(\%)\end{array}$ \\
\hline Ampicillin & 12.4 & 87.6 & 1.6 & 98.4 \\
\hline Ampicillin + Sulbactam & 58.3 & 41.7 & 0 & 100 \\
\hline Amoxilin & 10.1 & 89.9 & 4.8 & 95.2 \\
\hline $\begin{array}{l}\text { Amoxilin + Cluvanic } \\
\text { Acid }\end{array}$ & 35.8 & 65.2 & 25.5 & 74.5 \\
\hline Nalidixid Acid & 43.1 & 56.9 & 25.4 & 74.6 \\
\hline Tetracylin & 8.8 & 91.2 & 16.7 & 83.3 \\
\hline Cholaramphenicol & 25.6 & 74.4 & 30 & 70 \\
\hline Erithromycin & 10.3 & 89.7 & 5.3 & 94.7 \\
\hline $\begin{array}{l}\text { Sulfametrhoxazole + } \\
\text { Trimetrhoprime }\end{array}$ & 19.5 & 80.5 & 18.1 & 81.9 \\
\hline Nitrfurantion & 31.9 & 68.1 & 26.7 & 73.3 \\
\hline Gentamycin & 45.2 & 54.8 & 34.1 & 65.9 \\
\hline Ciprofloxacin & 50.3 & 49.7 & 44.4 & 55.6 \\
\hline Ceftriaxone & 40.9 & 69.1 & 16.4 & 83.6 \\
\hline Ceftazidim & 56.5 & 43.5 & 35.9 & 64.1 \\
\hline Netilmicin & 76.9 & 23.1 & 0 & 100 \\
\hline Cefoperazone & 25.9 & 74.1 & 15 & 85 \\
\hline $\begin{array}{l}\text { Sulbactam + } \\
\text { Cefoperazone }\end{array}$ & 50 & 50 & 25 & 75 \\
\hline Meropenem & 86.9 & 13.1 & 76.4 & 23.6 \\
\hline Fosfomycin & 73.2 & 26.8 & 41.7 & 58.3 \\
\hline Levofloxacin & 62 & 38 & 65.6 & 34.4 \\
\hline Vancomicin & - & - & 100 & 0 \\
\hline
\end{tabular}

Berdasarkan tabel 4 Escherichia coli sensitif terhadap meropenem (86,9\%) dan netilmisin $(76,9 \%)$, namun resisten terhadap tetrasiklin $(91,2 \%)$ dan amoksisilin (89,9\%). Klebsiella $s p$. sensitif terhadap meropenem $(76,4 \%)$ dan levofloksasin $(65,6 \%)$, tetapi resisten terhdap ampisilin-sulbaktam dan netilmisin (100\%). 
Pola Resistensi Antibiotik Terhadap Bakteri Pada Spesimen Sputum

Tabel 5. Pola resistensi antibiotik terhadap bakteri pada spesimen sputum di RSUP Dr. M. Djamil Padang tahun $\underline{2016}$

\begin{tabular}{|c|c|c|c|c|}
\hline \multirow[t]{2}{*}{ BAKTERI } & \multicolumn{2}{|c|}{$\begin{array}{c}\text { Klebsiella } \\
\text { sp. } \\
(n=20)\end{array}$} & \multicolumn{2}{|c|}{$\begin{array}{c}\text { Pseudomo } \\
\text { nas } \\
\text { Aeruginosa } \\
(\mathrm{n}=10)\end{array}$} \\
\hline & $\begin{array}{l}\mathrm{S} \\
(\%)\end{array}$ & $\begin{array}{l}\mathrm{R} \\
(\%)\end{array}$ & $\begin{array}{c}S \\
(\%)\end{array}$ & $\begin{array}{c}\mathrm{R} \\
(\%)\end{array}$ \\
\hline Ampicillin & 10 & 90 & 10 & 90 \\
\hline Amoxilin & 10.5 & 89.5 & 0 & 100 \\
\hline $\begin{array}{l}\text { Amoxilin + Cluvalanic } \\
\text { Acid }\end{array}$ & 33.3 & 66.7 & 14.3 & 85.7 \\
\hline $\begin{array}{l}\text { Chloramphenicol } \\
\text { Erithromycin }\end{array}$ & $\begin{array}{c}23.5 \\
6.2\end{array}$ & $\begin{array}{l}76.5 \\
93.8\end{array}$ & $\begin{array}{c}11.1 \\
0\end{array}$ & $\begin{array}{l}88.9 \\
100\end{array}$ \\
\hline $\begin{array}{l}\text { Sulfametrhoxazole + } \\
\text { Trimetrhoprime }\end{array}$ & 0 & 100 & 0 & 100 \\
\hline Nitrfurantion & 27.8 & 72.2 & 37.5 & 62.5 \\
\hline Gentamycin & 31.6 & 68.4 & 50 & 50 \\
\hline Cifrofloxacin & 45 & 55 & 50 & 50 \\
\hline Ceftriaxone & 26.3 & 73.7 & 33.3 & 66.7 \\
\hline Ceftazidim & 50 & 50 & 66.7 & 33.3 \\
\hline Cefoperazone & 22.2 & 77.8 & 57.1 & 42.9 \\
\hline Meropenem & 84.2 & 15.8 & 70 & 30 \\
\hline Fosfomicin & 50 & 50 & 42.9 & 57.1 \\
\hline Amikcin & - & - & 100 & 0 \\
\hline Levofloxacin & 76.9 & 23.1 & 75 & 25 \\
\hline
\end{tabular}

Berdasarkan tabel 5 Klebsiella sp. sensitif terhadap meropenem (84,2\%) dan levofloksasin $(76,9 \%)$, resisten terhadap sulfametroksazoltrimetroprim (100\%) dan eritromisin (93,8\%). Pseudomonas aeruginosa sensitif terhadap amikasin $(100 \%)$ dan levofloksasin $(75 \%)$ dan resisten terhadap amoksisilin, eritromisin, dan sulfametroksazoltrimetropim (100\%).

\section{PEMBAHASAN}

Dari penelitian ini didapatkan bakteri yang menjadi penyebab infeksi pada spesimen darah dari anak adalah Klebsiella sp. dan Staphylococcus aureus. Hasil ini sesuai dengan penelitian yang dilakukan oleh Tjekyan (2015) yang temuannya didominasi oleh bakteri tersebut. ${ }^{16}$ Hasil ini berbeda dengan penelitian yang dilakukan oleh Katarnida (2013) yang menemukan Salmonella typhi $(57,9 \%) .{ }^{17}$ Klebsiella sp. sensitif terhadap sulbaktam-sefoperazon dan netilmisin, dan rata-rata sudah resisten terhadap asam nalidiksat dan eritromisin. Sensitifitas pada antibiotik tersebut didukung juga karena antibiotik yang aktif terhadap bakteri Gram-negatif seperti Klebsiella sp. ${ }^{18}$ Resistensi yang terjadi dikarenakan eritromisin yang tidak aktif pada kebanyakan bakteri Gram-negatif. Sedangkan ampisilin dan amoksisilin walaupun memiliki spektrum yang luas, resistensi sudah banyak dilaporkan. ${ }^{19}$ Staphylococcus aureus sensitif terhadap ampisilinsulbaktam dan netilmisin, sedangkan resisten terhadap ampisilin dan amoksisilin. Staphylococcus aureus mengalami resistensi dikarenakan menghasilkan enzim betalaktamase yang menyebabkan tidak efektifnya ampisilin dan amoksilin dalam membunuh bakteri. Namun setelah dilakukan kombinasi dengan inhibitor betalaktamase (asam klavulanat dan sulbaktam), betalaktamse akan terikat dengan inhibitornya dan antibiotik dapat berfungsi dengan baik. ${ }^{20}$

Pada spesimen feses ditemukan Escherichia coli dan Klebsiella sp. Escherichia coli dan Klebsiella $s p$. adalah anggota dari flora normal usus. Bakteri tersebut biasanya tidak menyebabkan infeksi dan berperan dalam fungsi usus. Bila terjadi infeksi yang penting secara klinis, kemungkinan bakteri tersebut hidup di luar jaringannya atau hidup di bagian usus yang jarang flora normalnya. ${ }^{3}$ Escherichia coli sensitif terhadap sulbaktam-sefoperazon dan meropenem, resisten terhadap eritromisin dan ampisilin. Walaupun ampisilin memiliki aktivitas antibiotik yang luas, namun resistensi Escherichia coli terhadap antibiotik tersebut telah banyak dilaporkan mengalami resistensi. ${ }^{19} \mathrm{Hal}$ ini didukung dengan penelitian yang dilakukan oleh Katarnida (2013) yang menemukan ampisilin memiliki tingkat resistensi sebesar $87,5 \%{ }^{17}$ Klebsiella $s p$. sensitif terhadap netilmisin dan meropenem, namun resisten terhadap ampisilin, amoksisilin, dan eritromisin.

Pada spesimen urin ditemukan Escherichia coli dan Klebsiella sp. Hasil ini sesuai dengan penelitian yang dilakukan oleh Katarnida (2013) Escherichia coli 50\% dan Pratiwi (2013) Escherichia coli 58,5\% dan Klebsiella pneumoniae 13,2\%. ${ }^{17,21}$ Hasil berbeda ditunjukkan pada penelitian yang dilakukan oleh Tandari (2016) menemukan Pseudomonas sp. (17,8\%) sebagai bakteri yang paling banyak menjadi penyebab infeksi. ${ }^{22}$ Saluran kemih merupakan salah satu tempat yang paling sering terkena infeksi. Penyebab paling sering dari infeksi ini adalah Escherichia coli. ${ }^{3}$ Escherichia coli sensitif terhadap meropenem dan netilmisin, resisten terhadap tetrasiklin dan amoksisilin. Hasil ini sama dengan penelitian Tandari (2016) yang menemukan ampisilin, seftriakson, dan levofloksasin sudah resisten, sedangkan meropenem dan tetrasiklin masih sensitif. ${ }^{22}$ Hasil yang sama juga pada penelitian 
Katarnida (2013) hanya berbeda pada kloramfenikol yang masih sensitif. ${ }^{17}$ Temuan berbeda pada penelitian Pratiwi (2013) dengan seftriakson yang masih sensitif sebesar $55,5 \% .^{21}$ Klebsiella $s p$. sensitif terhadap meropenem dan levofloksasin, resisten terhadap ampisilin-sulbaktam dan netilmisin. Hasil yang sama ditemukan pada penelitian oleh Endriani (2010). ${ }^{23}$ Penelitian Tandari (2016) juga mendukung penelitian ini, hanya berbeda pada antibiotik levofloksasin yang mengalami resistensi sebesar $50 \% .^{22}$

Pada spesimen sputum ditemukan Klebsiella sp. dan Pseudomonas aeruginosa. Penelitian ini didukung oleh penelitian yang dilakukan oleh Sonita (2014) menemukan Klebsiella sp. sebesar $42,4 \% .{ }^{24} \mathrm{Hal}$ ini berbeda dengan penelitian yang dilakukan oleh Serviyanti (2013) yang menemukan Streptococcus non hemolisa (26,7\%) dan Baharutan (2015) yang menemukan Bacillus sp. (37,5\%) sebagai bakteri yang paling banyak ditemukan pada spesimen sputum. ${ }^{25,26}$ Klebsiella $s p$. sensitif terhadap meropenem dan levofloksasin, resisten terhadap sulfametroksazoltrimetroprim dan eritromisin. Hasil ini didukung oleh penelitian sebelumnya oleh Sulistyaningrum (2016). ${ }^{27}$ Pseudomonas aeruginosa sensitif terhadap amikasin dan levofloksasin, namun resisten terhadap amoksisilin, eritromisin, dan sulfametroksazol- trimetropim. Hasil ini berbeda dengan penelitian Hamdiyati (2016). Hampir semua antibiotik yang diujikan mengalami resistensi termasuk amikasin, levofloksasin, dan seftazidim. ${ }^{20}$ Temuan yang sama pada penelitian Sulistyaningrum (2016), levofloksasin juga telah resisten terhadap Pseudomonas aeruginosa. Namun pada penelitian Sulistyaningrum amikasin masih sensitif. ${ }^{27}$

\section{SIMPULAN}

Dari penelitian ini dapat disimpulkan bakteri yang paling banyak menjadi penyebab infeksi pada spesimen darah anak adalah Klebsiella sp. yang masih sensitif terhadap ciprofloksasin dan sudah resisten terhadap ampisilin. Pada spesimen feses adalah Escherichia coli yang masih sensitif terhadap meropenem dan sudah resisten terhadap eritromisin. Pada spesimen urin adalah Escherichia coli yang masih sensitif terhadap meropenem dan sudah resisten terhadap ampisilin. Pada spesimen sputum adalah Klebsiella sp. yang masih sensitif terhadap meropenem dan sudah resisten terhadap amoksisilin.

\section{DAFTAR PUSTAKA}

1. WHO. World Health Statistics: World Health Statistics 2015. Genewa; 2015; p. 55-86.

2. Mandell GL, Bennet JE, Dolin R. Principles and Practice of Infectious Diseases. Elsevier Book Aid; 2010. Hal.7.

3. Nugroho AW, translator. Brooks GF, Carroll KC, Butel JS, Morse SA, Mietzner TA. Mikrobiologi Kedokteran Jawetz, Melnick, \& Adelberg. Ed. 25. Jakarta: Penerbit Buku Kedokteran EGC; 2013.

4. Kronman MP, Zhou C, Mangione-Smith $\mathrm{R}$. Bacterial Prevalence and Antimicrobial Prescribing Trends For Acute Respiratory Track Infections. American Academy of Pediatrics. 2014; 134(4):956-65.

5. Ki V, Rotstein C. Bacterial Skin and Soft Tissue Infections In Adults: A Review of Their Epidemiology, Pathogenesis, Diagnosis, Treatment and Site of Care. Can J Infect Dis Med Microbiol. 2008; 19(2):173-84.

6. Fletcher SM, McLaws M, Ellis JT. Prevalence of Gastrointestinal Pathogens In Developed and Developing Countries: Systematic Review and Meta-Analysis. J Public Health Res. 2013; 2(1):4253.

7. Shaikh $\mathrm{N}$, Morone NE, Bost JE, Farrell $\mathrm{MH}$. Prevalence of Urinary Tract Infection in Childhood A Meta-Analysis. Pediatr Infect Dis J. 2008; 27:302-8.

8. Flores-Mireles $\mathrm{AL}$, Walker JN, Caparon M, Hultgren SJ. Urinary Tract Infections: Epidemiology, Mechanisms of Infection and Treatment Options. Nat Rev Microbiol. 2015; 13(5):269-84.

9. Setiabudi R. Pengantar Antimikroba. In: Farmakologi dan Terapi. 5th ed. Jakarta: Departemen Farmakologi Dan Terapeutik Fakultas Kedokteran Universitas Indonesia; 2007. p. 58598.

10. Schleiss MR. Infectious Disease: Antibiotic Therapy. In: Nelson Textbook Of Pediatrics. 18th ed. Elsevier; 2007.

11. Hapsari MM, Farida $H$, Keuter M, Hadi $U$, Sachro ADB. Penurunan Penggunaan Antibiotik Pada Pasien Anak Dengan Demam. Sari Pediatri. 2006; 8(1):16-24. 
12. Waggoner-Fountain LA. Infectious Disease: Preventive Measures. In: Nelson Textbook Of Pediatrics. 18th ed. Elsevier; 2007.

13. Kemenkes RI. Program Pengendalian Resistensi Antimikroba di Rumah Sakit. Jakarta: Kementrian Kesehatan RI; 2015.

14. Kemenkes RI. Pedoman Umum Penggunaan Antibiotik. Jakarta: Kementrian Kesehatan RI; 2011.

15. Imaniah BA. Peta Kuman dan Resistensinya terhadap Antibiotika pada Penderita Infeksi Saluran Kemih (ISK) di RSUD Dr. Moewardi Tahun 2014 (Skripsi). Fakultas Farmasi Universitas Muhammadiyah Surakarta; 2015.

16. Tjekyan RMS. Pola Kuman dan Resistensi Antibiotik di Pediatric Intensive Care Unit (PICU) RS. Dr. Mohammad Hoesin Palembang Tahun 2013. 2015; 2(2):91-7.

17. Katarnida SS, Karyanti MR, Oman DM, Katar Y. Pola Sensitifitas Bakteri dan Penggunaan Antibiotik. sari pediatri. 2013; 15(2):122-6.

18. Brunton LL, Chabner BA, Knollmann BC. Protein Synthesis Inhibitors and Miscellaneous Antibacterial Agents. In: Goodman \& Gilman's: The Pharmacological Basis of Therapeutics. 11th ed. The McGraw-Hill Companies, Inc.; p.725-27.

19. Istiantoro YH, Gan VHS. Penisilin, sefalosforin, dan antibiotik betalaktam lainnya. In: Farmakologi dan terapi. 5th ed. fakultas kedokteran universitas indonesia; p.664-86.

20. Hamdiyati R, Pinatih KJP, Fatmawati NND. Pola Mikroba Pasien Yang Dirawat Di Intensive Care Unit (ICU) Serta Kepekaannya Terhadap Antibiotik Di Rsup Sanglah Denpasar Bali Agustus-Oktober 2013. E-jurnal medika. 2016; 5(4):1-6.

21. Pratiwi DP. Kajian uji resistensi dan sensitifitas antibiotik ceftriaxone dan ciprofloxacin pada penderita infeksi saluran kemih di RSUP fatmawati (Skripsi). UIN Syarif Hidayatullah Jakarta; 2013.

22. Tandari AD. Pola Resistensi Bakteri Terhadap Antibiotik Pada Penderita Infeksi Saluran Kemih (Isk) Di Rumah Sakit X Periode Januari 2013 September $2015 \quad$ (Skripsi). Universitas Muhammadiyah Surakarta; 2016.

23. Endriani R, Andrini F, Alfina D. Pola Resistensi Bakteri Penyebab Infeksi Saluran Kemih (ISK)
Terhadap Antibakteri di Pekanbaru. Jurnal Natur Indonesia. 2010; 12(2):130-5.

24. Sonita A, Erly, Masri M. Pola Resistensi Bakteri pada Sputum Pasien PPOK Terhadap Beberapa Antibiotika di Laboratorium Mikrobiologi RSUP Dr.M.Djamil Periode 2010-2012. Jurnal Kesehatan Andalas. 2014; 3(3):354-7.

25. Serviyanti I, Soeliongan S, Kountul C. Pola Bakteri Dari Sputum Penderita Infeksi Saluran Pernapasan Di Puskesmas Bahu. Jurnal e-Biomedik. 2013; 1(1):325-9.

26. Baharutan KN, Fatimawali, Wullur A. Uji Kepekaan Bakteri Yang Diisolasi Dari Sputum Pasien Penderita Bronkitis Kronik Yang Menjalani Rawat Jalan Di Rsup Prof. Dr. R. D. Kandou Manado Terhadap Antibiotik Ampicilin, Eritromisin, Dan Ciprofloxacin. Pharmacon Jurnal IImiah Farmasi Unsrat. 2015; 4(4):139-46.

27. Sulistyaningrum R. Pola Resistensi Bakteri Terhadap Antibiotik Pada Penderita Pneumonia di Rumah Sakit X Periode Agustus 2013-Agustus 2015 (Skripsi). Universitas Muhammadiyah Surakarta; 2016. 